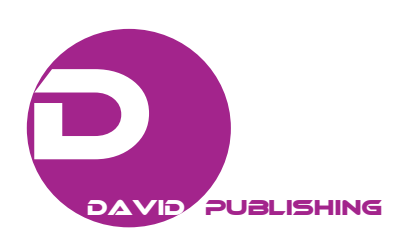

\title{
Lean Construction in Supply Chain Management: Supplier and Buyer Relationship in Social Housing
}

\author{
Aline Valverde Arrotéia, Tatiana Gondim do Amaral, Camilla Pompêo de Camargo e Silva and Mariana Franco \\ Pacheco \\ Program of Post Graduation in Geotechniques, Structures and Civil Construction, Federal University of Goiás, Goiânia 74605-220, \\ Brazil
}

\begin{abstract}
To the accomplishment of this article, we have chosen, as a case study, a small Goiana construction company that acted in the market of social housing. The main goal of this work is to analyze the fundamental aspects related to the management of the flow of supplies in civil construction to achieve a greater streamlining of logistic processes involved in supplying material. A checklist was developed for the purpose of data collection, and it was applied by means of an interview with the person in charge of the purchase department of the enterprise. In addition, this person is the engineer of the site. Taking into account the exploratory feature of this research, the construction site was visited so that some issues, such as quality aspects, losses, cleanliness and organization, could be observed. This on-site data collection visit was carried out through visual analyses and photographs. The obtained results were subdivided into a quantitative and a qualitative analysis. In this way, it was possible to see that the production process still has many phases to be improved. What is more, it was possible to see that the construction company knows its flaws and necessities to improve its processes although the final result does not have the expected quality. Being aware of this need for improvement, the construction company aims at having an affordable price product to the target public, especially when it is associated to an image that shows quality.
\end{abstract}

Key words: Lean construction, logistics and supply distribution, buyer and supplier relationship.

\section{Introduction}

The lack of concern in relation to the logistics management and the supply flow reflects negatively in the Brazilian civil construction in terms of productivity, quality and low level of provided service and in the final product. In general terms, the problems connected to the production lack of continuity are related to the low-quality project and also to a logistics management which is under-developed.

Thus, the logistics in the civil engineering chain supply seek for resolving problems, concerning the interruptions in the production, unnecessary stocks and the minimization in the material transport inside the construction site. By trying to resolve these problems, the civil engineering chain supply aims at having better productivity and reduction in costs. It is known that

Corresponding author: Tatiana Gondim do Amaral, Ph.D., professor, research field: management in construction. E-mail: tatiana_amaral@hotmail.com. civil construction is in need of both a continuous improvement in its constructive process and also in its general conditions in the construction sites. Such improvement would happen through an integrated view of every stage in the chain supply [1].

Therefore, this paper, for its exploratory feature, analyzed the fundamental aspects that are meant to be fulfilled in the civil construction chain supply management to achieve a better streamlining in the logistics processes involved with material supply.

\section{Bibliographic Review}

\subsection{Management in the Logistics of Civil Engineering Chain Supply}

Logistics in civil engineering is considered a multidisciplinary process applied to a certain civil work. Thereby, logistics has its goal on improving the supply, storage, processing and availability of materials and resources in the work fronts. In addition, 
it aims to provide the dimensioning of production teams and the management of physical production flows [2].

Consequently, the supply logistics play a strategic role as it operates in the production and supply interface besides having a significant contribution in the total costs of an enterprise. At the same time, the supply logistics is responsible for the interruptions at the workstations, as well as for the loss of productivity. This happens, as it is the cause of the delays in the production process due to the lack of material, equipment and so forth.

In this regard, the supply logistics management develops a series of activities that are cyclical and happen many times throughout the process. According to Ref. [3], they are: specification of the resources and supply planning; issuing and transmission of purchase requests; transport and receipt of the goods at the construction site; maintenance of the supply forecast in the planning (control and reprogramming).

\subsection{Just-in-Time System and Stock Reduction}

JIT (Just-in-Time) is based on the principle that strives to keep any activity under control so that it does not happen without the necessity in its production system. Similarly, no material or product in process should be at the usage or manufacturing site without the need of it at that moment. In other words, the production of the whole logistics chain must be oriented by the demand or final client [3].

According to the author, the high volume of inventory stocks and completed materials can be considered as a sign of waste. Consequently, the company is not able to become competitive in the market without recognizing that the two issues mentioned above do not add value to the product cost and, therefore, the company should try to eliminate them.

According to the construction management literature in Southern Africa [4, 5], the increased number of stakeholders, especially at the operational phase of project execution, necessitates the negotiation of improved decision making abilities within supply chains. The interfaces between suppliers, subcontractors and contractors imply that supply chain decisions affect the finished product. These interfaces may either accelerate or decrease the rate of production on sites based on project specific actions [6].

For the authors, the enhancement of how supply chain decisions are made and the "quality" of such decisions could drive out or reduce wasteful activities, and it then ensures that the finished product achieve expected ends. This discourse contributes to performance improvement related initiatives that are already on-going in the industry, especially as it affects developing economies. A future case study research endeavors should examine how supply chain decisions are made and their implications for construction in developing economies.

Thus, one may conclude that the application of the JIT management practices can offer significant contributions to the efficiency of logistics in the civil construction industry. This is true because this type of approach contributes to the cost reduction on inventories and finally it helps with the reduction of logistics total costs [3].

\subsection{Lean Thinking Applied to the Supply Chain}

Another aspect that plays a strategic role in production and also has a significant participation in general costs of an enterprise is the relationship between the buyer and the supplier. According to Fontanini [7], this is a conflicting relationship if one considers the buyer's constant demand to buy low-cost products but keeping good quality standards, as well as the planned production volume.

According to the discussions from lean thinking communit in a post-graduated course in 2008, the demands of the market require a new way of managing the supply chain and that is because the more united, fast and lean the chain supply is, the more success there will be in the market.

Construction supply chains tend to be fragmented 
due to the large number of different projects, suppliers and other direct (i.e., work force) and indirect (i.e., rental equipment) required resources. In addition, construction companies tend to be managed based on traditional project management methods. In this sense, problems found in construction supply chains can be attributed to the joint impact of increased fragmentation and inefficient methods for managing construction [8].

Fontanini [4], along with some other authors, such as Cooper and Slagmulder [5], Schonberger [9], Suzaki [10] and Womack et al. [11], present the supply flow behavior within the lean thinking and also discussed important features to the improvement of the relationship between the agents of the supply chain (in summary in Table 1).

\section{Research Methodology}

In the view of the exploratory feature of this paper, the research methodology chosen was based on the quantitative and on the qualitative analysis. A checklist was developed so that the quantitative analysis could be done. This checklist was applied to the person in charge of the purchase department of the enterprise (this person is also the engineer responsible for the site). On the other hand, the qualitative analyses were done through visits to the construction site. In addition to the visits, some other tools were used, such as photographs, visual analyses in relation to the quality aspects, losses, cleanliness and the organization of the site.

Table 1 Features of the buyer and supplier relationship within the lean system [7].

\begin{tabular}{|c|c|c|}
\hline \multicolumn{3}{|c|}{ Features of the buyer and supplier relationship within the lean system } \\
\hline \multicolumn{3}{|c|}{ Partnership } \\
\hline \multirow{4}{*}{ Authors } & Cooper and Slagmulder [5] & Through cooperative relationships and mutual benefits \\
\hline & Schonberger [9] & Long-term contract between suppliers \\
\hline & Suzaki $[10]$ & $\begin{array}{l}\text { Stable relationship between buyer and supplier with improvement for the } \\
\text { performance of both }\end{array}$ \\
\hline & Womack et al. [11] & $\begin{array}{l}\text { The agents of the supply chain are informed of the new discoveries and the } \\
\text { buyers provide support to the supplier so that the failures in relation to the } \\
\text { quality of the product can be corrected }\end{array}$ \\
\hline \multicolumn{3}{|c|}{ Stability of relationships } \\
\hline \multirow{3}{*}{ Authors } & Cooper and Slagmulder [5] & Achieved from the trust gained \\
\hline & Schonberger [9] & Repeated contracts with the same suppliers \\
\hline & Womack et al. [11] & $\begin{array}{l}\text { Buyer's and supplier's commitment to work together on a long-term run } \\
\text { with long-term contracts }\end{array}$ \\
\hline \multicolumn{3}{|c|}{ Bargaining power } \\
\hline Authors & Cooper and Slagmulder [5] & $\begin{array}{l}\text { Directly affects the relationship and commitment between the members of } \\
\text { the supply chain }\end{array}$ \\
\hline \multicolumn{3}{|c|}{ Cost reduction } \\
\hline \multirow{3}{*}{ Authors } & Cooper and Slagmulder [5] & Improvement of the costs between suppliers and buyers \\
\hline & Suzaki [10] & $\begin{array}{l}\text { Sharing of ideas for the improvement of costs must be assured by partner } \\
\text { companies }\end{array}$ \\
\hline & Womack et al. [11] & $\begin{array}{l}\text { Buyers' and suppliers' work in a rational framework for the determination } \\
\text { of costs, prices and profits providing mutual benefits }\end{array}$ \\
\hline \multicolumn{3}{|c|}{ Mutual benefits } \\
\hline Authors & Cooper and Slagmulder [5] & Suppliers and buyers should be able to benefit from each other \\
\hline \multicolumn{3}{|c|}{ Suppliers that are located nearby } \\
\hline Author & Schonberger [9] & $\begin{array}{l}\text { Suppliers should be grouped close to the buyer, if possible in cells within } \\
\text { the site of the company responsible for manufacturing the final product }\end{array}$ \\
\hline \multicolumn{3}{|c|}{ Joint effort } \\
\hline \multirow{2}{*}{ Authors } & Schonberger [9] & $\begin{array}{l}\text { Ensure the responsibility between each agent of the chain and the } \\
\text { reduction of the bureaucracy }\end{array}$ \\
\hline & Womack et al. [11] & $\begin{array}{l}\text { Buyers provide support to the supplier so that it is possible to correct any } \\
\text { problem which may be connected to the quality of the product }\end{array}$ \\
\hline
\end{tabular}


(Table 1 continued)

\begin{tabular}{|c|c|c|}
\hline \multicolumn{3}{|c|}{ Features of the buyer and supplier relationship within the lean system } \\
\hline \multicolumn{3}{|c|}{ Mutual learning } \\
\hline \multirow[b]{2}{*}{ Authors } & Schonberger [9] & Suppliers training \\
\hline & Womack et al. [11] & $\begin{array}{l}\text { The improvement of one member of the group ensures the continuous } \\
\text { improvement of the whole picture }\end{array}$ \\
\hline \multicolumn{3}{|c|}{ Information flow } \\
\hline \multirow{2}{*}{ Authors } & Cooper and Slagmulder [5] & $\begin{array}{l}\text { The information have to be divided among the members of the supply } \\
\text { chain }\end{array}$ \\
\hline & Womack et al. [11] & $\begin{array}{l}\text { The suppliers are informed in advance of the change in the production } \\
\text { volume }\end{array}$ \\
\hline \multicolumn{3}{|c|}{ Reducing the base of suppliers } \\
\hline \multirow{4}{*}{ Authors } & Cooper and Slagmulder [5] & $\begin{array}{l}\text { It can be in three ways: reducing of the suppliers for each part, reducing of } \\
\text { the suppliers per family (groups), reducing of the outsourced companies }\end{array}$ \\
\hline & Schonberger [9] & Listing a smaller number of qualified and dedicated suppliers \\
\hline & Suzaki [10] & $\begin{array}{l}\text { A smaller number of suppliers make the relationships and friendlier and } \\
\text { the reduction of costs become easier for both parts }\end{array}$ \\
\hline & Womack et al. [11] & $\begin{array}{l}\text { The buyer starts to work with a smaller number of suppliers, the choices } \\
\text { are based in past relationships as well as in a good performance record }\end{array}$ \\
\hline \multicolumn{3}{|c|}{ Delivery and production } \\
\hline \multirow{3}{*}{ Authors } & Schonberger [9] & $\begin{array}{l}\text { Motivation so that the suppliers use the Just-in-Time system, with reduced } \\
\text { dimensions and with a lower capacity program }\end{array}$ \\
\hline & Suzaki [10] & $\begin{array}{l}\text { The deliveries should be frequent and in small amounts. They should also } \\
\text { be done within the time limit and develop a flow of material between the } \\
\text { supplier and the buyer }\end{array}$ \\
\hline & Womack et al. [11] & $\begin{array}{l}\text { Using the Just-in-Time system; the agents work at Heijunka (uniformity of } \\
\text { production) with autonomy to stop producing in case of a problem }\end{array}$ \\
\hline \multicolumn{3}{|c|}{ Guaranteed quality } \\
\hline \multirow{4}{*}{ Authors } & Cooper and Slagmulder [5] & The buyers and the suppliers talk about improvements in their relationship \\
\hline & Schonberger [9] & $\begin{array}{l}\text { Quality can be easily seen with the checking of projects, correction of own } \\
\text { mistakes and stoppage of the line if needed }\end{array}$ \\
\hline & Suzaki [10] & $\begin{array}{l}\text { The suppliers must guarantee the delivery, quality and cost to the buyer; } \\
\text { the idea of quality should be used whenever possible with the statistic } \\
\text { control of the processes }\end{array}$ \\
\hline & Womack et al. [11] & $\begin{array}{l}\text { The continuous evaluation of the suppliers and discussion about their } \\
\text { performance }\end{array}$ \\
\hline \multicolumn{3}{|c|}{ Continuous improvement } \\
\hline Author & Schonberger [9] & $\begin{array}{l}\text { The continuous learning Kaizen should be motivated so that it is possible } \\
\text { to promote quality, reduction of costs and meeting deadlines }\end{array}$ \\
\hline
\end{tabular}

The checklist was divided into 13 different aspects concerning the lean thinking principles and the relationship buyer and supplier. This was done to promote some improvements in the supply chain and also optimize the supply flow in civil constructions. The 13 aspects mentioned above are: partnership, stability of relationships, democratic bargaining power, cost reduction, mutual benefits, close location, joint effort, mutual learning, information flow, reducing the base of suppliers, delivery and production, guaranteed quality and continuous improvement.

Based on the information above, a certain score was addressed to the checklist items. This grade varied from 0 to 5 so that the checklist would be able to identify the level of the supply management in the buyer and supplier relationship within the company in focus on this paper (as can be seen in Table 2).

The questions that guided the investigation of each aspect approached two general aims. The first one is to identify if there is the usage of such aspect by the company in the buyer and supplier relationship, and the second one is to identify the level of this aspect in the relationship. By observing Table 3, it is possible to see the questions. 
Table 2 Checklist score to the rating of the buyer and supplier relationship in HIS.

\begin{tabular}{ll}
\hline Score & Supply management-buyer and supplier relationship \\
\hline 0 & No presence in the context observed/no knowledge about the theme \\
1 & Initial studies of the topic \\
2 & Thorough understanding of the theme, but no tool used \\
3 & First time to try to use the tools in any process in the company \\
4 & Presence of some tools, but without formal awareness \\
5 & Tools used in varied processes of the company \\
\hline
\end{tabular}

Table 3 Checklist to the rating of the buyer and supplier relationship in HIS.

Questionnaire: supply management-buyer and supplier relationship

\begin{tabular}{|c|c|c|c|c|c|c|}
\hline Partnership & 0 & 1 & 2 & 3 & 4 & 5 \\
\hline
\end{tabular}

$1 \quad$ Does the company have long-term contracts with any supplier?

Rank the partnership with the suppliers

Possibility of starting a partnership with other companies

The partners (companies) have clear understanding of their duties, benefits, costs and

possibility of exchange

2 The company is satisfied with the performance of the partners

There are implicit and explicit guarantees with the companies (partners)

Dissatisfaction is higher than the benefits

None of the above

Stability of relationships

$\begin{array}{llllll}0 & 1 & 2 & 3 & 4 & 5\end{array}$

$1 \quad$ Does the company have any repeated long-term contract with any supplier?

2 In the basic contract with the suppliers, are there rules in relation to prices, guaranteed quality

2 and deliveries?

\begin{tabular}{lllllll}
\hline Bargaining power & 0 & 1 & 2 & 3 & 4 & 5
\end{tabular}

1 Does the company have facilities to negotiate with the supplier?

If so, rank it according to both companies:

The wish of one company is privileged

2 The company group as a whole has the power to negotiate

There is a powdered way to coordinate it

None of the above

\begin{tabular}{|c|c|c|c|c|c|c|c|}
\hline & reduction & 0 & 1 & 2 & 3 & 4 & 5 \\
\hline 1 & $\begin{array}{l}\text { Does the company work with its suppliers in a national structure to determine costs, prices } \\
\text { and profits for mutual benefits? }\end{array}$ & & & & & & \\
\hline 2 & $\begin{array}{l}\text { Is there enough conversation and sharing of ideas with the suppliers so that the costs are } \\
\text { improved (taking into account that good prices are essential)? }\end{array}$ & & & & & & \\
\hline & ual benefits & 0 & 1 & 2 & 3 & 4 & 5 \\
\hline 1 & Does the company work with any type of profit-sharing program with the suppliers? & & & & & & \\
\hline 2 & $\begin{array}{l}\text { Does the company work with any kind of stimulus with the suppliers so that they are able to } \\
\text { invest in new technologies with the objective of reducing costs and guarantee quality? }\end{array}$ & & & & & & \\
\hline & oliers that are located nearby & 0 & 1 & 2 & 3 & 4 & 5 \\
\hline 1 & $\begin{array}{l}\text { Is there any technical and information exchange in relation to the supply flow with the supply } \\
\text { companies? }\end{array}$ & & & & & & \\
\hline 2 & $\begin{array}{l}\text { Are the suppliers able to use any space in the construction site so that the supply flow is } \\
\text { enhanced? }\end{array}$ & & & & & & \\
\hline & t effort & 0 & 1 & 2 & 3 & 4 & 5 \\
\hline 1 & Does the company guarantee the responsibility between each agent in the productive chain? & & & & & & \\
\hline 2 & $\begin{array}{l}\text { Does the company guarantee support to the suppliers so that any type of problem in relation to } \\
\text { the quality of the product can be corrected? }\end{array}$ & & & & & & \\
\hline
\end{tabular}


(Table 3 continued)

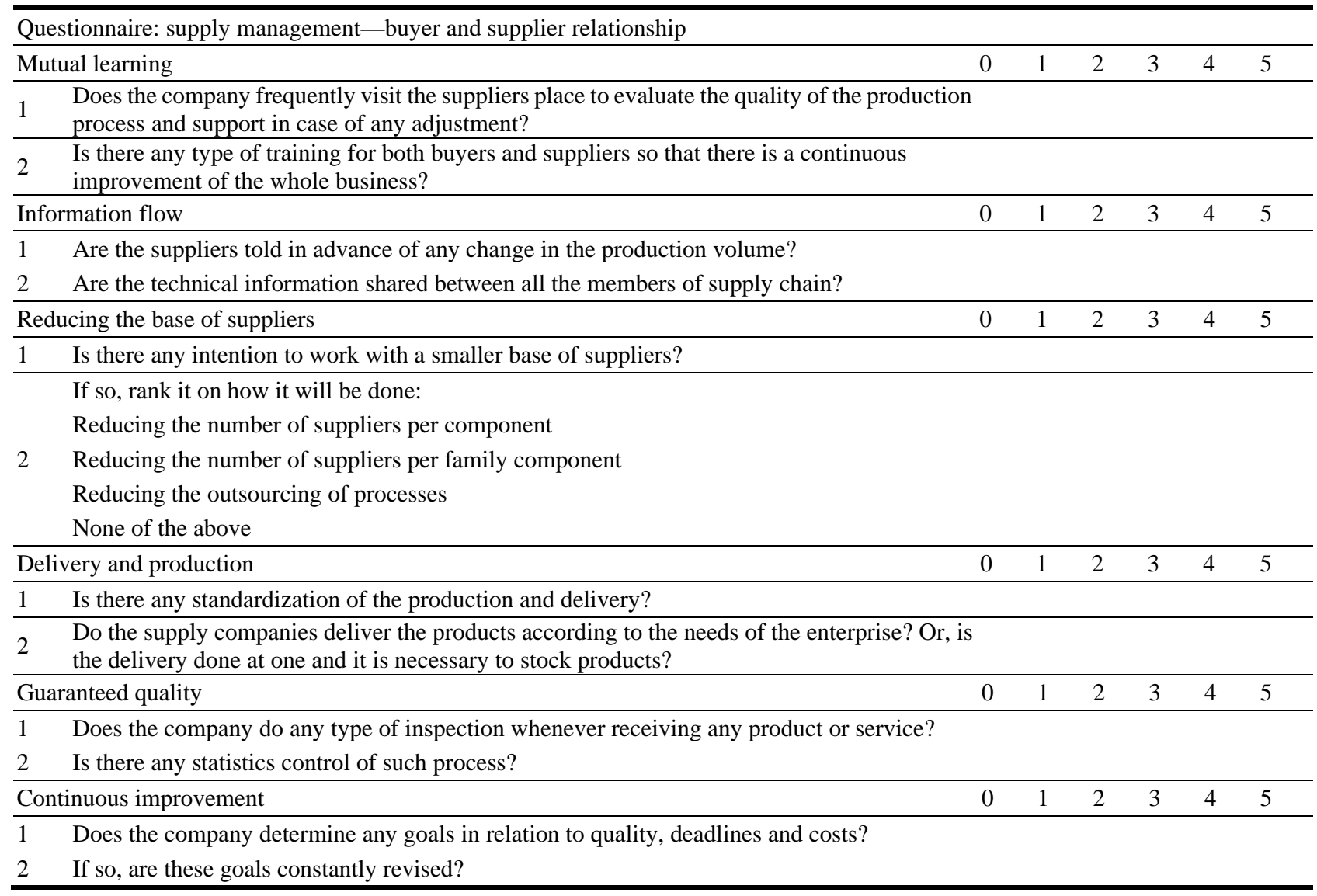

\section{Case Study}

The following issues were taken into account at the moment of selecting the company: (1) if the construction company had its focus on the market of HIS (social housing); (2) if the company had a certification on Quality Management System (ISO 9001:2008 or PBQP-H - in Portuguese); (3) if it is in a stage of implementation. But it was also considered if the company worked in Goiânia or in the surroundings and was interested in the research.

\subsection{Description of the Company}

The studied company is a construction company that has been in the field of social housing for three years. During these days, it is focused on the funding program of “CEF (Caixa Econômica Federal)”, named "Minha Casa, Minhavida”. The company is not certified yet but has been currently working on the implementation of the PBPQ-H (Brazilian Program for Productivity and
Quality of Habitat) (in Portuguese) in its processes, as it is a requirement of "CEF" in relation to the funding program “Minha Casa, Minhavida”. The company also shows concern regarding quality and continuous improvement by investing in the workers' training, rationalization and improvement of its processes. The company has 18 employees in the administration area and about 90 workers in the production area. It has also worked in Aparecida de Goiânia, Goiás on social housing. This enterprise is on the run and will probably be concluded in February 2012. It is a similar enterprise to the one in Goianira, Goiás that is studied in this research. The company still has a project that is on its initial phase in Gurupi, Tocantins.

\subsection{Description of the Enterprise}

The enterprise to be studied in this research is a complex social housing located in Goianira, Goiás. It is composed by 117 units with $89 \mathrm{~m}^{2}$ (each). Of this total 
$70 \mathrm{~m}^{2}$ is indoors, and $19 \mathrm{~m}^{2}$ is a verandah. Each house has two bedrooms, a suite-on bedroom, a living room, a kitchen, a social toilet and a verandah with space for the service area (which is open) as it is illustrated in Fig. 1.

\section{Analyses and Discussions of Results}

\subsection{Quantitative Analyses}

It was observed that there is a certain difference in relation to the presence of the lean construction principles. While some principles were $100 \%$ covered (the situation of the "bargaining power"), others did not show any result (situation of the "mutual benefits"). Such difference can be connected to the fact that the company is new in the market.

The company has approximately three different suppliers per material. At the purchase moment, it is analyzed which one offers the best prices so that the shopping can be done.

On the other hand, some other materials have a fixed company to buy from which provides what the construction company is in need of. This is the case of the ceramic, cement and ceramic block. According to the company, the negotiation is considered good as the supply company has a good marketing image for them and show credibility.

By looking forward to having better construction quality and also implementing the PBQP-H program, the construction company requires that the supply companies (such as the ones that sell ceramic blocks) have a quality certification (ISO 9001 in Portuguese) as a means to maintaining the partnership. This type of requirement can also be seen as a way to motivate the technological aspects of the suppliers. The company tries to keep the suppliers informed about the planning of the enterprise so that the supply company can organize its production in a better way. This happens as there are some materials that are bought in different demands throughout the project, and it is the case of the cement and sand.

Forms to check the service and the supply receipt service have been developed to guarantee the quality of the whole process.

By applying the questionnaire presented in the methodology, it was possible to elaborate a graph illustrated in Fig. 2 so that the results could be better visualized.

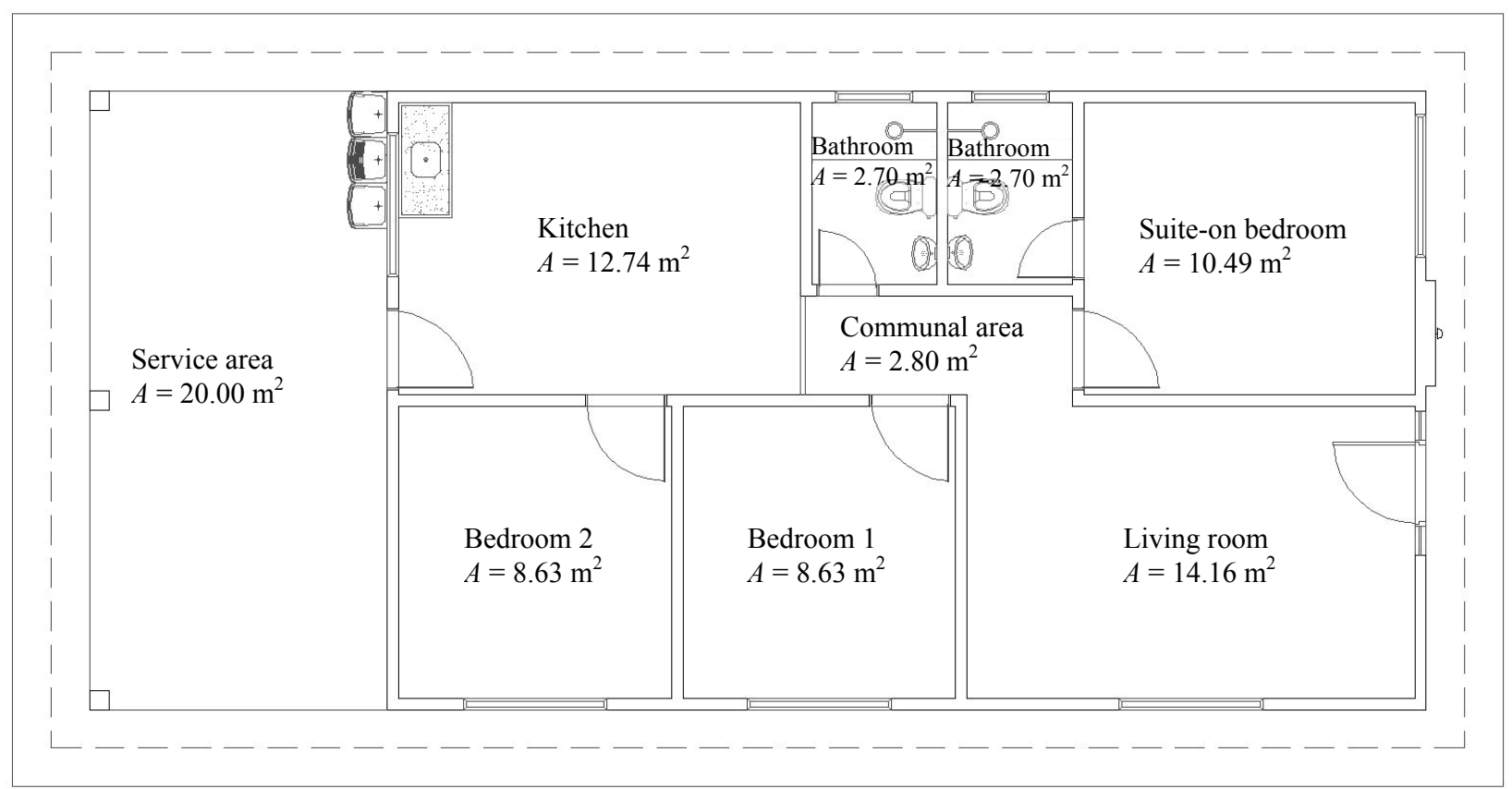

Fig. 1 The ground floor plan of the enterprise chosen to be studied. 


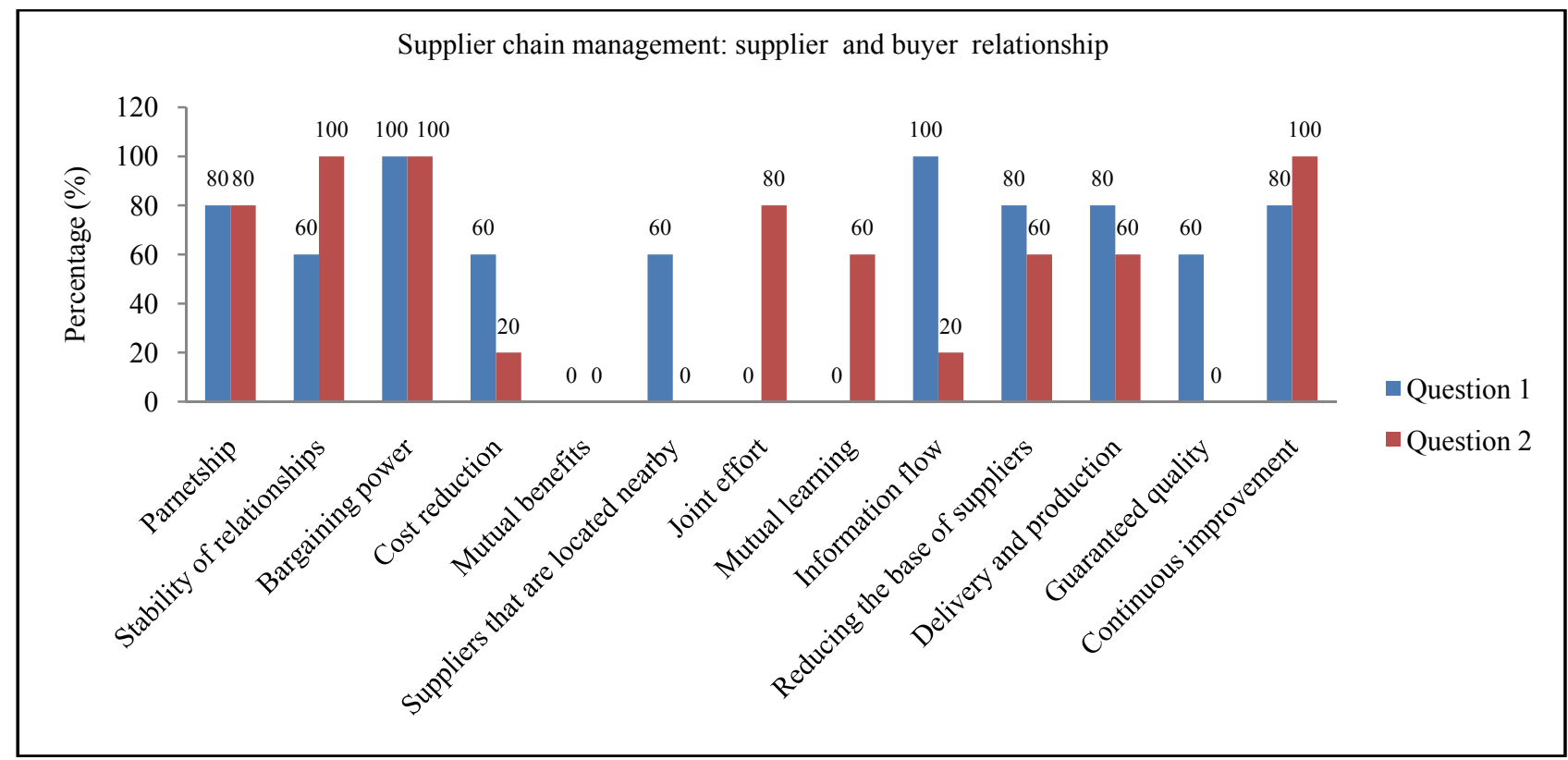

Fig. 2 Graph of the lean aspects in the supply management-buyer and supplier relationship.

\subsection{Qualitative Analyses of the Production Process and}

\section{Construction Site}

This analysis was done from the authors' point of view from the moments they visited the site, as well as based on the information given by the engineer. Besides, the analyses were done according to some questions asked to him at the moment of the visits. Some aspects were observed, such as construction technology, quality, safety and the mechanization of the process.

It was observed that the construction technology used by the company can be considered traditional as it does not show any type of technological innovation proposed in the project.

Because of that, we can assure that the company still does not see the important and fundamental role that the project plays in the execution process. We say that, as the project is responsible for the solutions that provide the continuous improvement in the process.

In the productive process, the low training profile of the workers ends up in poor results in the execution in HIS. Besides, the outsourcing of the workers to the production hinders a better control on them.

On this scenario, the company identified the low training profile of the workers as one of its most difficult problems to face. However, the company has been planning the change for the use of their own workers. Although the company uses the traditional construction method (masonry block ceramic) executed in a manual form, it has been under a transition. A part of the production is being mechanized using the bobcat and other equipment's. Nevertheless, the company is also investing in their own-trained workers as they intend to promote the control of their processes. Disorganization and lack of cleanliness at the construction site were also observed. Another critical issue was the lack of safety at work once some workers did not use the safety equipment's properly (individual production equipment). The engineer justifies all these issues by stating that it is difficult to control as the workers are outsourced.

\section{Conclusions and Final Considerations}

In conclusion, according to the data collected during the interview and in the visits to the construction site, it was possible to see that the production process is still in need of improvements in some stages. Although the production does not have the expected quality, the company admits its flaws and the necessity of improvements. The company admits that as they intend 
to offer a better product with a good and reasonable price to their clients, especially with a valued image in the market.

The studied company has been going through a restructuring moment as they have the aim of changing their workers that are nowadays outsourced. They intend to have better quality with their own workers. To do that, they invest in training of their partners with lectures and courses and motivating them to invest in their professional development. This is true, as the director (who is also a partner) believes that managing people is one of the pillars of his company.

This way, other actions can be mentioned as a part of their production planning. These actions are: raising production by investing in the workers training, streamlining parts of the production process so that the flaws are minimized and industrializing the execution at the construction site. And, also to enhance the internal processes of the company through the implementation of the PBQP-H, the company improves on daily basis in the market, offering infrastructure to the suppliers in the upcoming sites to a better integration in the productive process.

These actions done by the company reflect maturity in its management as it shows concern in identifying their flaws. Maturity in management is reassured in the fact that the company acts in the sense of not repeating the same mistakes in the future, making a stronger company name in the market. We suggest developing a new research in this company within a year approximately so that it is possible to see the changes that happened and the improvements that were reached.

\section{References}

[1] Vieira, H. F. 2002. "Technology Logistics in Product Development in Construction." Presented at II National Workshop: Project Management of the Process in Building Construction, Camboriu, Anais, Brazil.

[2] Oliveira, O. J. 2001. "Influences of the Production Design and Construction Project in the Logistics System of Building Construction.” M.Sc. thesis, University of São Paulo.

[3] Silva, F. B. 2000. "Concepts and Guidelines for Logistics Management in Building Production Process." M.Sc. thesis, Escola Politécnica da Universidade de São Paulo.

[4] Comunidade Lean Thinking. 2008. "Supply Chain Management." Comunidade Lean Thinking. Accessed December 5, 2011. http://www.leanthinkingcommunity. o rg.

[5] Cooper, R., and Slagmulder, R. 1999. Supply Chain Development for Lean Enterprise: Inter-organizational Cost Management. 1st ed. Oregon: Productivity.

[6] Emuze, F., and Smallwood, J. 2013. "Lean Supply Chain Decisions Implications for Construction in a Developing Economy." Presented at 21th Annual Conference of the International Group for Lean Construction, Fortaleza, Brazil.

[7] Fontanini, P. S. P. 2003. "Lean Thinking in the Supply Flow of Construction-Application Macro Mapping in the Chain of Aluminum Frames Providers." M.Sc. thesis, Universidade Estadual de Campinas.

[8] Souza, D. V. S. D., and Koskela, L. 2014. "Interfaces, Flows and Problems of Construction Supply Chains-A Case Study in Brazil." Presented at 22nd Annual Conference of the International Group for Lean Construction, Oslo, Norway.

[9] Schonberger, R. J. 1984. Influences of the Production Design and Construction Project in the Logistics System of Building Construction. São Paulo: Pioneira.

[10] Suzaki, K. 1987. The New Manufacturing Challenge: Techniques for Continuous Improvement. New York: The Free Press.

[11] Womack, J. P., Jones, D. T., and Roos, D. A. 1992. Machine that Changed the World. Rio de Janeiro: Campus. (in Portuguese) 